\title{
A Study of Religious Events during the End of Qing Dynasty in Eastern Zhejiang
}

\author{
Xianwei Xia \\ Zhejiang Radio \& TV University, Hangzhou, China \\ Email: xiaxianwei1989@163.com
}

How to cite this paper: Xia, X.W. (2020) A Study of Religious Events during the End of Qing Dynasty in Eastern Zhejiang. Open Access Library Journal, 7: e6405.

https://doi.org/10.4236/oalib.1106405

Received: May 8, 2020

Accepted: November 3, 2020

Published: November 6, 2020

Copyright $\odot 2020$ by author(s) and Open Access Library Inc.

This work is licensed under the Creative Commons Attribution International License (CC BY 4.0).

http://creativecommons.org/licenses/by/4.0/

\section{(c) (i) Open Access}

\begin{abstract}
Religious event is an important chapter and the longest mass movement and historical event in China's modern history. As one of the earliest open ports, Eastern Zhejiang was a region where western missionaries were in a high frequency and so as the religious events. Dinghai, which had been fallen for twice and occupied for six times, was especially such a place where religious events appeared. People of Zhenhai, Taizhou and Ninghai also launched lots of religious events, constantly giving more than their share of punishment. This paper will sort out and analyse the most important religious events during the end of Qing Dynasty in Eastern Zhejiang. We hope to make a clear understanding of the religious events happened in Eastern Zhejiang.
\end{abstract}

\section{Subject Areas}

History

\section{Keywords}

End of Qing Dynasty, Eastern Zhejiang, Religious Event

\section{Introduction}

Religious event is an important chapter in China's modern history and the longest mass movement and historical event in China's modern history. As one of the earliest port opening areas [1], eastern Zhejiang is an important area of missionary activities and one of the frequent occurrences of religious events. These religious events show the aggressive courage of the people of eastern Zhejiang, demonstrate the high patriotism of the people of eastern Zhejiang, and reflect the differences between the cultures of the East and the West. 


\section{The Spread of Catholicism in Ningbo after the Opium War}

The introduction of Catholicism to Ningbo can be traced back to the late Ming Dynasty. In 1638, Louis Buglio, an Italian missionary, travelled to Ningbo to preach, and Zhu Zongyuan, a native of Yinxian County, became the first Catholic in Ningbo. Reference [2] shows that in the early Qing Dynasty, Catholicism continued its development in Ningbo. On March 22, 1692, Emperor Kangxi issued a series of encyclical orders on March 17, March 19, March 20 and March 22 , which were praised by Westerners as the "1692 Royal Decree on Tolerance". Reference [3] shows that since then, Chinese Catholicism has entered the "golden age". During the forty-one years of ruling under Kangxi (1702), the French missionary Charles de Broissia built a church at the entrance of the Niqiao Lane in Ningbo. However, the Catholic Church in Ningbo was severely beaten after Emperor Yongzheng laid a ban on religion in 1724 [4].

After the signing of the Nanjing Treaty, the British forced the Qing government to sign the Five Trade Charter and Trade with sticky aftermath clause as a supplement in 1843. The United States and France took advantage of China's misfortunes and forced the Qing government to sign the Treaty of Wangxia and the Treaty of Whampoa in 1844. The first Opium War and a series of unequal treaties seriously undermined China's sovereignty. Aggression from European and American capitalist forces, which started from the southeast coast of China, gradually spread in a wider area.

After the Opium War, according to the Treaty of Nanjing, Ningbo was the port of trade. Through a series of unequal treaties, Britain, France and other capitalist countries in Ningbo seized consular jurisdiction, foreign residence area management, agreement customs rights. At the same time, Britain, France and other capitalist countries in Ningbo north shore consulate. So that Ningbo entered a semi-colonial and semi-feudal society, the people of Ningbo were not only oppressed by feudal rulers, but also bullied by Western powers. At the same time, Western religious culture has also infiltrated. During the war, Western missionaries had come to Ningbo and built places for worship in Dinghai in 1842. After the war, the invaders misinterpreted and expanded the relevant provisions of the unequal treaty while forcing the establishment of church churches in Ningbo, Dinghai, Zhenhai and other places in order to preach and teach Catholicism and to absorb Chinese believers.

As the executor of the infiltration of religious culture, missionaries are more convenient to run around than diplomats, and have more relative stability than businessmen, so it is best to engage in espionage. In 1847, the Holy See designated Zhejiang as a substitute pastoral area, sent Shi Boduo as substitute pastoral bishop, to Ningbo activities. In 1856, the Catholic Church occupied the land on the north bank of Ningbo Yongjiang River, built a "small holy temple", and set up a Catholic invasion base in Zhejiang. After the Second Opium War, they made four more efforts to develop their religious friends in order to expand the forces of aggression, while seizing land and plundering property in various plac- 
es on the basis of the so-called "restitution" of the Catholic property confiscated in the past in the Beijing Treaty between China and France [1].

As an open coastal city, Ningbo was among the pioneers accepting the modern civilization from the West. The first group transmitting information of modern culture to Ningbo was church organizations and missionaries. Western-style schools, hospitals and newspapers run by missionaries were not only the product of the cultural aggression of western powers but also the pioneer of Ningbo's modern cultural transformation. They acted as a medium of exchange between Chinese and Western culture, though there were twists and turns, but after all, it was conducive to the modernization of Ningbo culture.

In general, the capitalist countries of Europe and the United States, forced the Qing government to open the port of Ningbo with the attack of warship artillery, and the missionaries followed, and their shackles of economic exploitation and ideological enslavement on the people of Zhejiang became even more serious. The religious event in eastern Zhejiang was born against this background

\section{Main Religious Events in Eastern Zhejiang in Late Qing Dynasty}

In the face of the invasion of foreign invading forces, the people of eastern Zhejiang made unremitting fight against aggression. In Dinghai, which had experienced two falls and six defeats, people's resistance was particularly strong. People in Zhenhai, Taizhou, Ninghai also launched the anti-religious battles and continued to give the invaders due punishment [2]. British ambassador to china Bruce later admitted that the group of aggressors "were criminal, eventually forced the people up to seek revenge with mass atrocities". "Atrocity" and "revenge", as Bruce said, are the righteous struggle against aggression in eastern Zhejiang. The following is a brief introduction to the main religious events in eastern Zhejiang during the late Qing Dynasty.

\subsection{The Religious Event of Dinghai in 1851}

The signing of the unequal treaty gave western missionaries the privilege of plunder, which made some of them change from evangelists to economic predators and political oppressors [1]. Most of the clerics, who had come from a low background and a poor life, greedily plundered Chinese wealth when they came to China. One of them was the French missionary Gu Zede. As early as 1844, French missionary Gu Zede sent Chinese missionary Fang Anzhi to set up a church in Dinghai, the incident of people's resistance occurred, but just after the war was over, the Qing court gave unprincipled protection to the missionaries as it was afraid of provoking troubles. By February 1846, the Qing court permitted "the return of properties", from then on "negotiations regarding the return of old properties" occurred in various places. Dinghai religious event was brewing in this situation.

In December 1851, with the support of the Chinese priest Wan Anzhi, the believers took the opportunity to occupy several temples and monasteries in 
Dinghai City, which was opposed by the people of Dinghai. Historical records: at that time, the French missionary Gu Zede sent to the church in Dinghai city, the lure of fang a forced the people "repeatedly village temples and monasteries into the church, occupy the control of the village, scholars because of their repeated harassment, the masses of grievances", is gathered villagers, "excommunication, take back the occupied monastery" [2].

Immediately after the religious event, French priest Gu Zede accompanied the country's consul in Shanghai Montigny to Ningbo and Dinghai, threatening local officials, asked the local authorities to immediately "punish villagers severely and escort the temple", or "warships will be soon ready to make an attack on the places" [3]. Chang Dachun, the governor of Zhejiang, refused this unreasonable request from French consul and ordered Dao Tai and other subordinate officials to "unite the hearts of the people in order to subdue and eradicate the chance of enforced obedience" and "investigate, arrest and sentence the criminals with no biased asylum in any form" [5] for those outlaws among the religious followers. However, while the Qing Dynasty was busy fighting the Taiping army, the government asked officials across the country that "that excessive and harsh demands should not be encouraged for fear of side issues" [6]. Since the imperial edict showed weakness, local bureaucrats had to obey and act according to it, but they kept their promises and minimize the effects of religious events.

\subsection{The Religious Event of Haimen in $\mathbf{1 8 5 1}$}

Zhejiang Haimen was an area under the heavy influence of French Catholic. Li Sicong, the local French Catholic priest, was an arrogant person. Gangster in Huangyan county southeast joined the church and bullied people due to the protection from the church. Ying Wande, a farmer in this area and living close to the Catholic church, was often bullied by west priests and thus grew radical hatred of the west churches.

After the rise of the Boxer Movement in Northern China, Ying Wande formed an alliance together with Xia Jinfu and Wang Wuchen from the same village to rebel against religion. On February $18^{\text {th }}$ in 1899 , Yingwande led more than ten people to Haimen. The French Catholic priest, Li Sicong, forced the local government to arrest Ying Wande. Once getting the news, Ying Wande secretly aksed his son Ying Zaileng to lead the anti-Church masses of more than a thousand, who were armed with guns and equipment, and surround the church. It was only because of the obstacle made by local officials that the Haimen Church was not demolished. But the flames of anti-imperialist struggle did not extinguish, the group immediately travelled to Yangyu to demolish the churches there and made revenge on the Chinese priest Ruan Xiaoben, who usually bullied people and wore foreign clothes by "crowing his eyes and feet and expelling him out of the border" [1]. On the 19th, Ying Wande led 200 or 300 members of the congregation to the nearby villages and called on them to "protect the country and destroy the religion" and to "benefit all those who follow it". The day of February $21^{\text {st }}$ was the official day of uprising. The next day saw the uprising tra- 
velled from Huangmao Mount to Zeku of Taiping County and burnt the churches along the way. Under the leadership of Ying Wande, eleven churches in Jingquan, Maolin, Luqiao and Taiping counties were burned down, and the rebellion forces rapidly developed to Huangyan, Taiping, Linhai three counties.

Ying Wande's anti-religious struggle was responded by the places all over the province. "Local villagers heard the name of the matter and demolished and deconstructed their local churches." For example, in Ningbo Xixiang, Daqiao and other places, there were "noisy gatherings and huge impacts", scared the local church of foreign priests who then fled to hide [2]. More than 2000 people from Yuyao flocked to the local Jesuit Church to denounce priests and religious people.

After the religious event in Haimen, the governor of Zhejiang Liu Shutang reported that "Taizhou missionary Ruan acted imperiously and the agency should order him to leave the area of Taizhou" [3]. This religious event led by Ying Wande "was caused and stimulated by the Catholic believers" [2]. Taizhou held the largest group of Catholic believers in Zhejiang Province and the parishioners behaved in a particularly arrogant and imperious way. The missionaries regarded the religion as a protection umbrella under which they exploited the local people and committed all manners of crimes, leading to the intension of relationship between the missionaries and the villagers. This was the cause of the anti-religion event. Therefore, it was requested that the priests and missionaries in Taizhou should be sent away from Taizhou.

Still, the case Religious Event of Haimen was not brought to an end independently. Soon, the Boxer Movement broke out, Zhejiang Province set off a magnificent mass anti-imperialist revolutionary movement, and the church forces were under a hard attack again. Until the $27^{\text {th }}$ year of Emperor GuangXu (1901), according to the Charter of Religious Events in Zhejiang, the former Haimen guerrilla Liu Xianbin "conspired with bandits and held radical hatred to the church and he should be dismissed from his position and never be employed again. Compensations, which valued a total of 180,000 liang, were delivered to the churches and families of believers" [1]. The Religious Event of Haimen was then ended until two years later when the Charter of Religious Events was established.

\subsection{The Anti-Church Event Wang Xitong of Ninghai in 1900}

At the end of the 19th century, the plot of the great powers to divide China became clearer, the economic aggression deepened day by day, and the church forces became more rampant, thus causing the three major crises of the belief, nationality and survival of the Chinese nation. The crisis is becoming more serious, and the resistance struggle of the Chinese people is becoming more and more fierce. The Chinese people were forced to "die all the time, he is only heavy artillery fire, we are all accompanied by death, see he can shoot a few people. If you can't finish the fight, ten people will kill him one person, that's enough" [1]. Finally, the national-scale anti-imperialist patriotic Boxer Movement broke out.

During the Boxer Movement, Zhejiang's religious events spread to more than 
ten counties, destroying as many as ten churches and robbing and burning more than 1000 families of religious families. Ninghai Wang Xitong led the fight against the largest scale, the longest duration.

Ninghai, located in the east coast of Zhejiang, on the east of Xiangshan, on the west of Xinchang, on the south of Sanmen Bay and on the north of Fenghua, with blocked traffic and economic backwardness, was a poor county. But imperialism still extended its claws. Founded in 1856, Ningbo Catholic Church "small holy hall", with the Sino-French Treaty of Beijing, Tianjin Treaty in the "restitution of property confiscated in the past", "into the mainland missionary, local government must be generous to protect" provisions, go deep into the counties, seize land, build churches, expand the forces of aggression. In 1870, the first cathedral in Ninghai was built in Fengtan. Later, churches were built in Zhonghu, Dali, Huangtan and Chengguan [2]. The establishment of churches, the development of believers, the endless disaster brought to the people of Ninghai, the priests in the name of missionary, extorted and exploited local people.

Wang Xitong, a native of Dali Village, Beixiang, Ninghai County, had been teaching in the countryside and had a sense of justice and patriotism. He hated the infighting of the Ninghai Catholic Church and the invasion of the Eight-Power Allied Forces, and organized the Fuhu Society in the local area to unite the masses and make secret preparations.

In August 1900, when a religious event took place in Quzhou, Wang Xitong, the leader of the Fuhu Society, immediately took the opportunity to call on the local people to respond, and led 50 or 60 members of the congregation to uncover the pole in Dali, burn down the churches in Dali and Zhonghu, and crack down on those who did evil at ordinary times.

Ninghai county immediately led the army rushed to the big li suppression. Because the strength of the enemy, Wang Xitong guided the transfer of part of the Fuhu Society to Ningbo and Cixi areas for temporary dormancy.

After the Boxer Movement failed, Wang Xitong continued his struggle. In 1901 Qingming, he returned to Dali, again led the anti-religious, destroyed the reconstruction of Zhonghu church. In June, Sun Qitai, a county magistrate, lured Wang Xitong into the city and put him into prison. Wang's wife Chen Maoying led more than 100 people into the village rescue, along the way with thousands of people. After Chen Maoying went out of Xi Tong, Xi Tong went to Jiaxing and Huzhou, contacted the anti-religious forces, and returned to Dali in September 1903 to mobilize the masses to hold armed anti-religious uprising, attack the county seat, burn down the Ninghai Catholic Church, and execute the evil priests and religious people.

\subsection{The Second Religious Event of Ninghai in 1903}

After the defeat of the Boxer Movement, the Catholic Bishop of Ningbo and the Frenchman Zhao Paul sent Zhu Guoguang to Ninghai as a priest. At this time, Ninghai Catholics grew more arrogant with their affiliation to the church forces 
and power. They went to those people who had participated in the fight against the church as an excuse for mass extortion. Among them, Yan Yongkang, Luo Renshou and Wang Jiatuan were among the most ferocious, and the masses hated them and called them "Yan Luo Wang" [1]. Ninghai people in unbearable circumstances, sent to invite Wang Xitong back to the county, leading them to armed resistance.

In August 1903, Ninghai sounded the trumpet of the anti-imperialist struggle as the Bishop Zhao Paul celebrated his 50th birthday. The leader of the uprising was Wang Xitong led Fuhu Soceity.

After Wang Xitong returned from his hometown, he called for the "extermination of Catholicism", and the people of all villages signed up enthusiastically. September 26, 1903 drama in the flag of the uprising, "from the clouds." On the same day, they joined the nearby anti-church masses, attacked the county town, divided the road and burned two churches inside and outside the city, executed the god father Zhu Guoguang. Ninghai people's uprising received the response of the people everywhere. People in Haimen, Huangtan, Taizhou rose against the church with a rapid development of the uprising team, during which the killing evil tyrants and religious believers Luo Renshou and others greatly inspired the people's fighting spirit.

After Wang Xitong's uprising, France sent the "Bascale" ship into the Yongjiang Estuary to threaten, and forced the Qing government to quickly suppress. Zhejiang Governor NiesorghumSend Taizhou Zhifu Xu Chengli sit Zhenning Hai, transfer Taiwan state government county Qing army, Ningbo government also sent hundreds of Qing army, "and with the French soldiers dozens back to Ninghai", full suppression.

In this tense crisis, Wang Xitong with "the church has been destroyed, the priest has been killed, the usual hatred so released", relaxed the spirit and vigilance. On October 10th the Qing army besieged Dari. After several battles, eventually because of the military strength, firearms disparity, the Rebellion important leader release monk, Zhou Shengui and so on war dead. Ye Mingxiu, Chen Asan and Wang Xitong son Wang Yousheng have been captured, Wang Xitong was forced to flee to Shengxian, Qing government with 8000 gold reward. His whereabouts were unknown.

In 1904, Zhejiang local officials and the Catholic bishop in Zhejiang Zhao Paul draw up "Ninghai lesson plan discussion knot". The main contents are as follows: 1) Compensation of 130,000; 2) In Hangzhou and Dinghai, churches were allowed to house fields; 3) The protection of churches and the strict handling of religious leaders and the masses (listed by the clergy to be pursued by local officials); 4) In civil disputes, local officials were required to investigate the case of priests; 5) Officials were investigated and discharged for their failure in protecting the churches; 6) Compensations were delivered to the church followers [1]. There was a frenzied crackdown on the anti-religious community, causing a tragic scene in Dari village. 


\subsection{The Religious Event of Ninghai in 1905}

Ninghai County god people Ge Shihao, by the people and god people Ge Fengtan and others, because of feud killed. Ge Shihao's son Ge Jin Dou, this matter reported to the county magistrate Zhang Daling. Then, Zhang ordered immediately sent a reward for clues, gather the battalion to take the murderer.

Soon, Ma Fangyong and Yang Shichang and the son of the deceased Ge Jindou, together with the news of the murderer, they hid in the village near Shadi. So, on the night of June $17^{\text {th }}$, they searched the village of Sha Di. By the fifth shift, the search party was temporarily resting in the corridor and was attacked by about 50 or 60 people headed by Ge Fengtan. And they all took guns and other weapons into the search team rest of the corridor, rushed. Yang Shichang and others rose to fight with them, with a view to arresting criminals, but because of the lack of strength and cannot enemy. Ge Jindou and Fangyong Valley were killed in the melee, the rest of the people were also injured. Li Mou's injury was particularly serious and Ge Jindou's head was also cut off by the murderous bandit.

From 18 to $20^{\text {th }}$ of June, they fled from the sandbank to the small pavilion, through East Australia, sandbank and Haiyou West Cave and other places and posted false signs, leaflets, promote the elimination of such statements as church, the temptation to threaten villagers to leave school. Zhang Daling and Military Officer Hua with the supervision of Jiang, Chen, Ye three guard sentry, together to step up tracing efforts.

On the other hand, this group was defeated in the sea on the $21^{\text {st }}$ of June, escaped to Huayu Tang before landing. The land and houses of the Catholic Church in this place were burned down, and property was looted and ransomed and ransomed. Military Officer Hua then drove the boat and pursued the murderer by water. The arrest was supported by Arrest Officer of Taizhou, Military Officer Liu of Training Camp of Ningbo and the deputy Manger of Camp Chen Shao of Ningbo who received order before.

All the pursuit teams, from $22^{\text {nd }}$ to $24^{\text {th }}$ of June, successively arrived in Ninghai with intense defense in preparation to arrest fugitives. Zhang Daling and Military Officer Hua as well as Jiang, Chen, Ye three guard posts, were also on the $22^{\text {nd }}$ day in the sea tour Dongping and other places to hunt down the traces of bandits. Because the bandits shot and resisted arrest, the melee killed the fierce bandits Zhang Fengcai on the spot, injured gang accomplices Ge Chaoyu, Mao Congji, Chen Erjin, Yang Rongyan, Hu Fashui and other five people, immediately captured. The bandits were gone and could not resist before they began to flee. The official army seized the banners, leaflets and books from the bandits and took them with them to the county government [1]. The captured bandits, later seriously injured, soon died.

On the day of $24^{\text {th }}$, guard sentry Jiangmou in a place called Xiaopu captured bandits Zhang Fengfu, escorted back to the Ya Wen investigation. Only about the first offender Ge Fengtan, there is escape into the sea, but also by the Wu Ji leader sent the navy to arrest. 


\subsection{The Religious Event of Zhang Xiaojin in Xiangshan in 1907}

In the first month of 1907, Xiangshan County Zhang Xiaojin, Ma Pei Xiang and others, on the grounds of rice expensive, united nearby hungry people. On the night of the $25^{\text {th }}$, begging from the new bridge church, destroyed the board wall bed cabinet and other things. Pastor Xiao Mengchuan invited the County Police Chief to check. On the half-way of returning on the 29th, just after the County Police Chief was released, Pastor Xiao was still locked in extortion. Wang Shengbao, Monk Kan'e went to the countryside searching for money and guns and bullets and getting ready to uprise. Four anti-religionists gathered on the night of February $3^{\text {rd }}$ in a temple in Xikou but were then surrounded by the patrol led by Chang Rongqing, who was shot and got injured. Wang Shengbao captured more than 30 people. The church was no longer a problem, and the priest Xiao Mengzhuan was fine. Wang Shengbao and other 13 people were sentenced to death on the spot, while the rest of the light criminals were thrown into prison or bailed. Ma Pixiang fled to Ninghai but got arrested finally. The case was calmed down then.

\section{Causes of Religious Events in Eastern Zhejiang}

Religious event is an important chapter in China's modern history and the longest mass movement and historical event in China's modern history. As one of the earliest port areas, eastern Zhejiang is an important area of missionary activities. Religious events also often occur, the causes are also very complex, the author mainly from the following aspects of shallow discussion.

First of all, the religious event is the main contradiction of modern Chinese society-the contradiction of the Chinese nation and the contradiction of imperialism is constantly intensified, and it is an important part of the Chinese people's opposition to the war of foreign aggression [1]. The introduction of modern Christianity into China in the late Qing Dynasty was very different from the Buddhism and Islam in history. It was not the crystallization of Chinese and Western cultural exchanges, but the component part and colonial tool of imperialist policy of invading China. In the first half of the nineteenth century, Western colonialism invaded China with the opium of cannons, pushing China step by step into the abyss of chaos, and aggravated the suffering of the Chinese people. According to the Treaty of Nanjing, Ningbo is a port of trade. After the opening of Ningbo, the western religious culture also infiltrated. During the war, Western missionaries had come to Ningbo and worshiped at Dinghai Jian Tang in 1842. After the war, the invaders misinterpreted and expanded the relevant provisions of the unequal treaty, forced the establishment of church churches in Ningbo, Dinghai, Zhenhai and other places, spread the Catholic and Jesus religions, and absorbed Chinese believers. Some of them became integrated into the local area by being western bullies with lots of land and privileges and feudal exploitation and oppression of peasants. It aroused the resistance of the people in eastern Zhejiang, thus triggering the religious event. 
Secondly, the contradiction between Christianity and Chinese feudal ethics is key to the occurrence of religious events in the eastern Zhejiang. The conflicts between Christianity and the political and religious customs of Chinese society are as follows: 1) the conflict between Christian theism and Confucian human-based theory; 2) the conflict between Christian monotheism and Chinese hierarchical order and traditional belief. Christianity advocates that believers should not believe in other ghosts and gods, only serve God for life, repent and save the soul. This is very different from the Confucian thought and the traditional custom of worshiping the ancestors of heaven, which makes the feudal gentry and the general people think it is intolerable. This contradiction is exacerbated by the Christian church and the pope's promotion of theocratic supremacy, the promulgation of a ban and the imposition of a forced ban on Chinese worshippers from respecting Confucianism and Taoist thought. 3) The conflict between church authority and Chinese secular Wang Quan.

Moreover, most of the religious events are directly caused by missionaries. The priest was the main target. Most of the priests returned to the church, property and interference from the word litigation. Foreign missionaries, relying on unequal treaties and the asylum of foreign embassies and consulates, often force the return of the old church sites, demanding public places, halls, academies, temples, etc. regardless of the actual situation, and some missionaries also forcibly buy fields, extort money at low prices and even occupy farmland. Whenever a religious event occurs, missionaries, regardless of the right or wrong, often force the magistrate to make a ruling in favour of the parishioners, and often falsely accuse the non-religious people involved in the case, sue the magistrate, or ask the minister to intervene with the prime minister's office. Priests and clergy want to protect their interests by this means, but often counterproductive, thus triggering lesson plans. For example, in 1852 Dinghai religious event, French missionaries and religious people occupied six temples and monasteries, officials and people negotiate with the "Catholic Church" to retake the temple [2]. In 1862, in Ningbo, missionary forced the demolition of houses near the church to expand the church, causing civil conflict, but the Qing court compromise, allowing priests to build the church [3].

In addition, the protection of the religious people by missionaries and the extension of extraterritorial jurisdiction to the enjoyment of the religious people is also an important cause of public indignation [4]. They are generally divided into three categories: the first is true believers, who are generally kind, and are taught only by the propaganda of missionaries; the second is religious, which has no faith; the second is religious, which is taught because life is very poor, the third is religious, which is an attempt to protect the interests of individuals or families by the forces of the church, most of whom are local tyrants [5]. The latter two groups are often the perpetrators of civil strife. The missionaries did not ask the right or wrong, took cover, even took their lawsuit, and forced the magistrate to give in. Under the cover of missionaries, there is nothing to be done about the scum of the church. For example, in 1906, Xianju, Taizhou, the godfa- 
ther Wang Hongfan opened the county government notice, causing trouble. County police Xiong Shiguo went to bring a message, but by the church department to correct the beating, and detained in the church. County orders to negotiate with the church, the church refused to let people [1].

Finally, in the international community, "weak countries have no diplomacy", the occurrence of religious events in eastern Zhejiang in the late Qing Dynasty has a great relationship with the diplomacy of the late Qing government. The weakness of the Qing government contrasts with the strength of the Western powers, which makes the Qing government defensive in diplomacy. The Qing government didn't contain the religious event effectively, but it caused more public indignation, which is also the important reason of the religious event in eastern Zhejiang.

In short, the religious event of eastern Zhejiang in the late Qing Dynasty continued to occur since the Opium War, the reasons are very complex, both historical and political and cultural reasons, and also inseparable from the diplomacy of the Qing government. Missionaries rely on a series of unequal treaties, tyrants-occupied lands, interference in local justice and internal affairs, directly led to the occurrence of some religious events in eastern Zhejiang. At the same time, the conflict between Christian culture relying on power aggression and Confucian culture subjected to power aggression has also become the internal driving force of the religious event storm in modern China. The incompetence and weakness of the Qing government in diplomacy also led to endless religious events. As an open area of China's coastal ports of trade, religious events occur frequently.

\section{Characteristics of Religious Events in Eastern Zhejiang in the Late Qing Dynasty}

Since the religious event of Dinghai in 1844, which was caused by the French missionary $\mathrm{Gu}$, people of eastern Zhejiang have made great contributions to China's struggle against the Church. It has its own characteristics:

First, its struggle has always been directed at the imperialist aggressors. Imperialists stigmatize the occurrence of Chinese religious events and reject foreign cultures. This is an excuse from imperialism for its aggression. As we all know, the introduction of foreign religions into China did not begin in modern times. At the end of the Western Han Dynasty and the beginning of the Eastern Han Dynasty, Indian Buddhism was introduced into China, and later Islam was introduced. The introduction of these religions did not provoke resistance from the Chinese people. Instead, it took root on Chinese soil. The occurrence of religious events in the late Qing Dynasty was a manifestation of the Chinese people's struggle against aggression. Dinghai religious event 1851 to 1899 Haimen religious event and 1900 and 1903 Ninghai king Xitong anti-church uprising, the spearhead is directed at imperialist invaders and their absorption of illegal religious people. 
Second, there is no unified campaign of struggle. It has a simple common slogan against foreign forces and oppression. From the course of the development of the religious event in eastern Zhejiang, it is difficult to put forward a unified action slogan because of the complexity of the components of the input movement and the different positions and by each. From Dinghai religious event in 1851 to Haimen religious plan in 1899, Ninghai Wang Xitong anti-church uprising in 1900 and 1903, Zhejiang Ningbo religious event in April 1902, which was caused by rumors, to Ninghai religious event in 1905 and Zhang Xiaojin religious event in Xiangshan County in 1907, there and no lofty struggle goal.

Third, secret societies played a leading role in the struggle. The Ninghai religious event in 1900 and the second Ninghai religious evnet in 1903 took place under the leadership of Fuhu Society led by Wang Xitong. This makes the struggle more cohesive and centripetal. With a core of leadership, the struggle is not too fragmented.

Fourth, rumors played a role in the struggle, such as the April 1902 religious event in Ningbo, Zhejiang Province, rumors spread that missionaries in the "charity hall", "nursery hall" to maim children, dig their eyes. The people gathered together to attack the church and beat the master. Finally, after the investigation as a rumor, people can settle.

Fifth, the conflict between the people and religion is the trigger. The causes of religious events in eastern Zhejiang are very complicated, but most of them are caused by the conflict between people and education. Most of them are caused by bad behavior. Missionaries and the people of the same spirit, rampant, its performance has three: one is to intervene in litigation, the other is to cover up hidden criminals, the third is to connive the people for evil. In this way, the church forces have in fact formed a new special ruling group over the people. In 1862, Ningbo missionaries expand the church, the demolition of houses near the church, causing civil conflict. In the same year, Haimen a church occupied a widow's old-age fields, was opposed by the people, and finally the priest plot succeeded. In 1905, the people of Cixi were forced to rent Da Ci-an, causing disputes. Ninghai Catholics grew more arrogant with their affiliation to the church forces and power. They went to those people who had participated in the fight against the church as an excuse for mass extortion. The two religious events in 1900 and 1903 share similar the fuse of occurrence.

Sixthly, although the religious event shows religious and cultural conflicts in the external form, it is often caused by property disputes and is directly related to economic interests. There are not a few conflicts between the people and the church caused by the return of the old church site. Because the government has to respond to the church, often "private, refers to return to the church. So there comes that "gentry people have high house giant room, hard refers to the church of that year, forced the folk to return, and even will hinder the system of the land and public offices, pavilions, temples for the most respected by the gentry, all arbitrarily claim to the church. That is to say, if it is sold by the people of the past year, and later sold by the folk, it is no longer a master, and there is a huge cost 
of re-repair, the priest cannot pay the value, forced to return; by the occasional dumping of houses, the cost of repair". This cannot but arouse the resentment of the local people, so many religious events. In 1852, the French missionaries and the religious people occupied six temples and monasteries in Dinghai, and the officials and the people negotiated with the "Catholic Church", which triggered the religious event and finally retaken the temple. In 1895 Dinghai priests coveted four thousand acres of monks, to the church fire, framed monks. The governor Liao Shoufeng does not ask the reason namely orders the monk to compensate Tu Tian $2000 \mathrm{mu}$, thus causes the religious event.

\section{Conclusion}

The struggles and fights in the religious events in eastern Zhejiang in the late Qing Dynasty had a great blindness as they blurred the boundary between the general religious activities and the imperialist use of religion to carry out aggression, and its own organization was very backward. But its unremitting struggle shows the high patriotism of the people of eastern Zhejiang and the boundless vitality, and has made great contributions to China's struggle against aggression.

\section{Acknowledgements}

This article is the research results of Zhejiang Radio and Television University's Teaching Studio "Internet plus Ideological and Political Work".

\section{Conflicts of Interest}

The author declares no conflicts of interest regarding the publication of this paper.

\section{References}

[1] Gong, Y.Y. (2006) Eastern Zhejiang Scholars and Western Studies in Ming and Qing Dynasties. Journal of Zhejiang University, 3, 60-68.

[2] Gong, Y.Y. (2007) Several Catholic Cases during the Region of Emperor Kangxi-A Study of Chinese Literature in Biblioteca Apostolica Vaticana. Social Science Front, 4, 294-297.

[3] Gong, Y.Y. (2010) The History of Early Christianin Zhejiang. Hangzhou Publishing Group, Hangzhou.

[4] Jia, Z., et al. (1979) The Beginning and the End of Preparing Foreigner Affairs. Zhonghua Book Company, Beijing.

[5] Wang, Y.W. (1970) Eastern Journal. Taiwan Commercial Press, Taipei.

[6] Xu, H.Y. and Zheng, Y.S. (1982) Modern History in Zhejiang. Zhejiang People Publishing Group, Hangzhou. 